\title{
The Impact of Public Investment on Private Investment: A Disaggregated Analysis
}

\author{
Noman SAEED, Kalim Hyder, and Asghar Ali
}

\section{INTRODUCTION}

The impact of public investment on private investment has been a matter of great interest in economic literature. Classical economists believed that public investment crowds out private investment. While Keynesian economists counter this argument and argued that public investment increases or crowds in private investment because of the multiplier effect. Many of the empirical studies have directly examined this by testing whether a statistically significant relationship exists or not, between public investment and private investment. The empirical work appears with mixed statistical results on the relationship between public and private investment. Results of Erenburg and Wohar (1995), Pereira (2001, 2003), Pereira and Roca-Sagales (2001), Hyder (2002) and Naqvi (2002) showed that public investment crowds in private investment while Pradhan, Ratha and Sarma (1990), Haque and Montiel (1993), Ahmed (1994), Voss (2002) and Narayan (2004) showed that public investment crowds out private investment.

The debate on the role of public sector in expanding or squeezing private sector in Pakistan was raised when Pakistan pursued a policy of fiscal consolidation in 1988 in which budget deficit were controlled by curtailment of development expenditure. ${ }^{1}$ Policy makers support their action by the argument that the increase in public investment leaves fewer funds for private investment that leads to competition and thereby drive the interest rates up leading to lower level of private investment.

The crowding out hypothesis has so far been tested in Pakistan by analysing the impact of budget deficit on the interest rates [Ahmed (1994), Khan and Iqbal (1991) Burney and Yasmeen (1989)]. Some of these studies provide evidence of a negative relationship between budget deficit and interest rates implying that policy makers should

Noman Saeed <economanics@yahoo.com> and Asghar Ali <asgharplus@yahoo.com> are Project Economists at Applied Economics Research Centre, Karachi. Kalim Hyder <kalimhyder@hotmail.com> is Senior Research Fellow at Centre for Research, Lahore School of Economics, Lahore.

Authors' Note: The views expressed in this article are those of the authors and do not necessarily represent those of the institutions in which they work.

${ }^{1}$ Theoretically, development expenditure component of fiscal outlays equals net investment by the public sector in Pakistan. Public investment is constructed primarily by economic activity as well as by capital assets. It comprises expenditures incurred on the acquisition of fixed assets, replacement, additions, and major improvements of fixed capital, viz., land improvement, buildings, civil and engineering works, machinery, transport equipment, and furniture and fixtures. Whereas, expenditures incurred on the developmental activities are termed as development expenditures. 
increase public spending [Ahmed (1994), Khan and Iqbal (1991)]. Others connote a support for the crowding out hypothesis based on positive association between interest rates and budget deficit [Haque and Montiel (1993)]. Although this testing mechanism provides a direct way for testing in favor of or against crowding out, it cannot simplistically be applied to Pakistan, as private investment in Pakistan is not significantly related to interest rates. ${ }^{2}$

For the most part, the empirical work has been focused on the aggregate effect of public investment on private investment and indicates that there is positive, statistically significant relationship exists between public and private sector investment. In fact, a significant positive effect of public investment at the aggregate level does not provide any information to the sectoral incidence of such effects. It is possible that small effects at the aggregate level could hide significant effects for specific sector. In this paper, we examine the effects of public investment on private investment of different sectors (Agriculture, Manufacturing and Overall) of the economy. This approach allows us to determine which sectors of private investment are crowded in by public investment.

The rest of the paper is organised as follows. In the second section, we review the existing empirical literature on crowding out hypothesis, especially with reference to Pakistan. The third section summarises theoretical framework for testing the crowding out hypothesis. In the fourth section, we review the multivariate time series techniques essential for estimating our model. The fifth section presents and discusses empirical results. Finally, in section six, major conclusions are outlined and policy recommendations are provided for future research.

\section{LITERATURE RIVIEW}

As discussed in introduction, many researchers have focused their attention to examine the effects of public investment on private investment and present mixed results. Erenburg and Wohar (1995) examined the causal linkage between private investment and government provision of public capital and government investment spending and indicate the existence of feedback effects between public and private investment. Alfredo M. Pereira (2001) investigated the effects of Public investment and Private investment in United States. The empirical results suggested that at the aggregate level Public investment crowds in Private investment.

Pradhan, Ratha, and Sarma (1990) examined the question of complementarity between public and private investment in India and found that public investment crowds out private investment. Voss (2002) using data for both the United States and Canada and showed that for both countries there is no evidence of crowding in between public and private investment; in fact, innovations to public investment tend to crowd out private investment. Narayan (2004) investigated using the error correction mechanism test, whether government investment crowds out or crowds in private investment for Fiji by dividing the sample into two and found that government and private investments are cointegrated over the period 1950-1975, but not for the period 1976-2001. They also found that in the former period government investment has crowded in private investment, while in the latter period the relationship between government and private investments has been statistically weak.

${ }^{2}$ Macro expenditure module, Macro-econometric model of SPDC, Karachi. 
If we observe literature on crowding out hypothesis particularly in the case of Pakistan, we found that the hypothesis has been tested by analysing the impact of budget deficit on interest rate. If budget deficit causes a displacement of private investment, a link should exist between budget deficit and interest rates. The overall deficit is found to have a significant impact on the nominal interest rate, which leads to the crowding out of private investment expenditure. Haque and Montiel (1993) support the crowding out hypothesis in Pakistan by providing positive association between interest rate and budget deficit. Ahmed (1994) provides evidence of a negative relationship between budget deficit and interest rate. Implying Public investment has a positive relationship with the Private investment. Burney and Yasmeen (1989) examined the impact of government budget deficit on interest rate and showed no significant relationship exist between overall fiscal deficit and nominal interest rate, from this they concluded that there is no support to the crowding out hypothesis in Pakistan. Hyder (2001) shows a positive correlation between Public and Private Investment, thereby implying the absence of crowding out hypothesis in Pakistan. Naqvi (2002) using the co-integrating VAR's suggests that public investment has a positive impact on private investment.

The effect of public investment at the aggregate level does not provide any information regarding the sectoral incidence of such effects. Probably due to the lack of consensus on the issue of the aggregate effects of the public investment, the effect of public investment across different industries (sector) has been largely neglected. Indeed, studies with a sectoral focus are not abundant. Looney (1994) analysed the effect of different type of public investment on private investment of agriculture sector and concluded that, there is negative relationship between Public Sector Program and Private Investment in Agriculture, Rural work has weak positive impact on Private Investment in Agriculture, while Indus Basin Investment has a negative effect on Private Investment in Agriculture. Looney (1995) using granger Causality test, suggested that Public Investment has not played an important role in Private Investment and showed that Public Investment crowd out Private Investment in Manufacturing. Looney (1999) suggested that Private investment has been discouraged by the Public Capital Formation in Manufacturing. Not only government investment in this area shifted the private sector but it has diverted funds away from productive activities.

Pereira and Roca-Sagales (2001) analysed the effects of public capital formation on private sector performance for both aggregate and disaggregated sectoral level in Spain. The empirical results at the aggregate level indicate that public capital crowds in private inputs and affects private output positively. The positive effects of public capital formation also detected at the disaggregated level. The sector of services seems to gain the most in absolute terms. In relative terms, however, all sectors, except for agriculture, benefit in some way. The sector of services captures a disproportionate share of the benefits in terms of private capital formation while manufacturing and construction benefit disproportionately in terms of employment and output. These results also imply that public capital formation makes the sector of services more capital-intensive and the manufacturing sector more labour-intensive. Pereira (2001) uses a vector autoregressive/error correction mechanism (VAR/ECM) approach to evaluate empirically 
aggregate and the disaggregated effects of public capital formation on private sector performance at the industry level. Empirical results at the aggregate level indicate that public investment affects positively private inputs and output. Empirical results at industry level suggests that public investment affects private investment positively only in 5 of 12 industries.

Since empirical work yields different results, Overall picture along with the disaggregated analysis seems to be quite useful in concluding the debate of crowding out of private investment due to increase in public investment. In this paper, dynamics of overall public investment, private investment and GDP are explored along with the analysis of commodity producing sectors (Agriculture and Manufacturing) of the economy.

\section{THEORETICAL FRAMEWORK}

The interaction between public and private investment can be visualised in several different ways. Firstly, an increase in public investment in heavily subsidised and inefficient state-owned enterprises in various sectors more often reduces the possibilities for private investment and long run growth. Secondly, increase in public investment as a component of aggregate demand will increase economic growth. Furthermore, improvement in the economic and social infrastructure due to increased public spending will result in higher rate of return on private capital, which will ultimately encourage private investment. Thirdly, increase in private investment places pressure on the government to expand infrastructural facilities. The economic managers wishing to aid private investment and simultaneously lacking adequate funding for major infrastructural programs may first grant the private sector various forms of relief such as tax holidays and exemptions followed by modest increase in public investment. This might result in higher budget deficits but not a crowding out of private investment.

The impact of public investment on capital formation in the private sector can possibly be analysed by using a modified neoclassical production function. ${ }^{3} \mathrm{~A}$ neoclassical production function could then be written with separate arguments for public and private capital stocks:

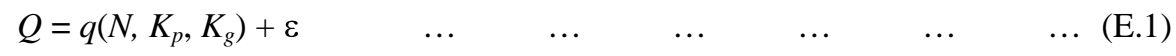

In the above equation, $Q$ denotes the level of real output, $N$ denotes employment, $K_{p}$ denotes the stock of private capital and $K_{g}$ refers to the public capital stock. e denotes a shift parameter of the production function which may account for Solow-type technical change as well as any other irregularities in the production process.

With this specification, it is possible to analyse the interaction between private and public capital formation and their impact on the level of output and employment. It provides an indirect means for examining crowding out by testing whether public and private capital stocks are substitutes or compliments to each other. If public and private capital stocks appear substitutes of each other, then an increase in the supply of public

${ }^{3}$ Barth and Cordes (1980), Aschauer (1988) and Ramirez (1994). 
capital would drive out private capital from production. ${ }^{4}$ If, however, they are complements in nature, then an increase in the public capital stock will reinforce an increase in the private capital stock by enhancing its productivity. Furthermore, the positive impact of increase in public capital stock on the marginal productivity of private capital stock and labour productivity will increase output. If both public and private capital stocks are weakly substitutable or weakly complementary, then an increase in public capital will only have a positive impact on output.

\section{UNRESTRICTED STRUCTURAL VAR METHODOLOGY}

The VAR system is based on empirical regularities embedded in the data. The VAR model may be viewed as a system of reduced form equations in which each of the endogenous variables is regressed on its own lagged values and the legged values of all other variables in the system.

An $n$ variable VAR system can be written as:

$$
\begin{array}{cccccccc}
A(l) Y_{t}=A+U_{t} & \ldots & \ldots & \ldots & \ldots & \ldots & \ldots & \ldots \\
\text { and } A(l)=l-A_{l} l-A_{2} l^{2}-\ldots A_{m} l^{m} & \ldots & \ldots & \ldots & \ldots & \ldots
\end{array}
$$

Where $Y_{t}$ is an $n x l$ vector of macroeconomic variables, A is an $n x l$ vector of constraints, and $U_{t}$ is an $n x l$ vector of random variables, each of which is serially uncorrelated with constant variance and zero mean. Equation (2) is an $n x n$ matrix of normalised polynomials in the lag operator $l\left(l_{y t}^{k}=Y_{t-k}\right)$ with the first entry of each polynomial on A's being unity.

Since the error terms $\left(U_{t}\right)$ in the above model are serially uncorrelated, an ordinary least squares (OLS) technique would be appropriate to estimate this model. However, before estimating the parameters of the model $A(l)$ meaningfully, one must limit the length of the lag in the polynomials. If $l$ is the lag length, the number of coefficients to be estimated is $n(n l+c)$, where $c$ is the number of constants.

In the VAR model above, the current innovations $\left(U_{t}\right)$ are unanticipated but become parts of the information set in the next period. This implies that the anticipated impact of a variable is captured in the coefficients of lagged polynomials while the residuals capture unforeseen contemporaneous events. Hence, even though a direct interpretation of the estimated individual coefficients from the VAR system is very difficult, a joint $F$-test on these lagged polynomials is, nevertheless, useful in providing information regarding the impact of the anticipated portion of the right-hand side variables.

${ }^{4}$ The Keynesian crowding out hypothesis is concerned with the demand rather than the supply side of the economy. It simply predicts that if the demand for goods increases in the public sector then the demand for capital goods by the private sector will decline because of the increase in the interest rate. However, due to the unavailability of data on demand counterparts of the variables included in our model, we base our test on the supply variables instead. This is why we call our testing mechanism an indirect one. From a purely empirical standpoint, the difference between demand and supply is never visible, as observed data is always the equilibrium quantity traded in the market. Some researchers have suggested specifying an automated adjustment mechanism to convert supply data into demand data. This, undisputedly results in the inclusion of AR(1) variable in the final estimated equation. Our econometric methodology adequately takes into account this issue. 
Therefore, an important feature of the VAR methodology is the use of the estimated residuals, called VAR innovation, in dynamic analysis. Unlike the traditional economic approach, these VAR innovations are treated as an intrinsic part of the system.

In order to analyse the impact of unanticipated policy shocks on the macro variables in a more convenient and comprehensive way, Sims (1990) proposed the use of impulse response functions (IRFs) and forecast error variance decompositions (FEVDs). IRFs and FEVDs are obtained from a moving average representation of the VAR model [Equations (1) and (2)] as shown below:

$$
\begin{array}{cccccccc}
Y_{t}=\text { Constant }+H_{t}(l) U & \ldots & \ldots & \ldots & \ldots & \ldots & \ldots & (3) \\
\text { and } H(l)=I+H_{t}^{l}+H_{2}^{l}+ & \ldots & \ldots & \ldots & \ldots & \ldots & \ldots & (4)
\end{array}
$$

Where $H$ is the coefficient matrix of the moving average representation which can be obtained by successive substitution in Equations (1) and (2). The elements of the $H$ matrix trace the response over time of a variable $i$ due to a unit shock given to variable $j$. In fact, these impulse response functions will provide the means to analyse the dynamic behavior of the target variables due to unanticipated shocks in the policy variables. This is because the IRFs trace the reaction of all the variables in the VAR system to innovations in one of the variables and therefore can be used to analyse the effects of structural innovations.

Having derived the variance-covariance from the moving-average representation, the FEVDs can be constructed. FEVDs represent the decomposition of forecast error variances and therefore give estimates of the contributions of distinct innovations to the variances. Thus, they can be interpreted as showing the portion of variance in the prediction for each variable in the system that is attributable to its own innovations and to shocks to other variables in the system.

Furthermore, another significant feature of VAR pertains to the treatment of policy variables. Unlike traditional modeling in which such variables are treated as exogenous, the VAR approach allows their determination by the specification of the reaction functions.

\section{EMPIRICAL RESULTS}

Before estimating the VAR, we investigate the time series properties of the variables ${ }^{5}$ used. To avoid the spurious regression problem in the case of using nonstationary time series causing unreliable correlations within the regression analysis, we used the variables in growth rates (approximated by logged differences). At first, by using the augmented Dickey-Fuller (1979) and Phillips-Perron (1988) unit root tests, we check for the stationarity condition of our variables. The optimal lag length is selected by using the AIC. The results are shown in table below.

${ }^{5}$ The description and the sources of variables are given in Appendix Table A-1. 
Table 1

Unit Root Tests

\begin{tabular}{lcccccccc}
\hline Variables & ADF & PP & Variables & ADF & PP & Variables & ADF & PP \\
\hline DLIPUBR & -3.61901 & -21.9627 & DLLA & -3.86544 & -32.7655 & DLLM & -2.84983 & -40.4638 \\
& $(0.028)$ & $(0.047)$ & & $(0.014)$ & $(0.005)$ & & $(0.179)$ & $(0.001)$ \\
DLLABIND & -3.77586 & -30.0454 & DLYSAR & -4.44517 & -37.2406 & DLYSMR & -2.10057 & -16.253 \\
& $(0.018)$ & $(0.009)$ & & $(0.002)$ & $(0.002)$ & & $(0.546)$ & $(0.147)$ \\
DLYSFCR & -2.76577 & -24.954 & DLIPAR & -3.79054 & -31.0582 & DLIPMR & -3.29233 & -23.7689 \\
& $(0.210)$ & $(0.026)$ & & $(0.017)$ & $(0.007)$ & & $(0.068)$ & $(0.033)$ \\
DLIPR & -4.02294 & -23.4326 & DLIGMR & -3.26074 & -33.5516 & DLIGAR & -4.61 & -4.92 \\
& $(0.008)$ & $(0.035)$ & & $(0.073)$ & $(0.004)$ & & $(0.001)$ & $(0.000)$ \\
\hline
\end{tabular}

Probabilities of rejection of null hypothesis are presented in parenthesis.

The results shows that all the variables are stationary when considered in growth rates. This suggests that if we had to choose between a VAR with all variables in log deviations from trend and a VAR in growth rates, the latter would be the appropriate choice, and thus we have estimated VAR with the variables in growth rate form. Unit root tests can, of course, have low power as has been well established, but these test results are at least consistent with our strong prior of a unit root in log-levels. Further, we will proceed in a manner in which results are presented by sector wise.

\section{Agriculture Sector}

The investigation of the relationship between the public investment and private investment in agriculture sector is started with the description of simple correlation of the variables.

Table 2

Correlation Matrix

\begin{tabular}{lcccc}
\hline & DLOG(IGAR) & DLOG(LA) & DLOG(IPAR) & DLOG(YSAR) \\
\hline DLOG(IGAR) & 1.00 & & & \\
DLOG(LA) & -0.35 & 1.00 & & \\
DLOG(IPAR) & 0.33 & -0.10 & 1.00 & \\
DLOG(YSAR) & 0.12 & 0.13 & -0.12 & 1.00 \\
\hline
\end{tabular}

The correlation matrix computed for sample (1974-2006) demonstrates a positive correlation between growth of public and private investment. Growth in labour demand is negatively correlated with growth of both type of investments but positively correlated with value added growth. Further, inputs growth has positive correlation with output growth. We first choose the lag order selected by minimised AIC statistics for our dynamic VAR specification that is 1 . The estimated VAR is reported below. 
Table 3

VAR Estimates of Agriculture Sector

\begin{tabular}{lcccc}
\hline & \multicolumn{4}{c}{ Dependent Variables } \\
\cline { 2 - 5 } Explanatory Variables & DLOG(IGAR) & DLOG(LA) & DLOG(IPAR) & DLOG(YSAR) \\
\hline \multirow{2}{*}{ DLOG(IGAR(-1)) } & 0.121867 & -0.007627 & 0.086617 & -0.003973 \\
& {$[0.49247]$} & {$[-0.49646]$} & {$[3.79626]$} & {$[-0.34285]$} \\
DLOG(LA(-1)) & 3.037596 & -0.341066 & 1.345563 & -0.25963 \\
& {$[0.79687]$} & {$[-1.44126]$} & {$[3.82840]$} & {$[-1.45460]$} \\
DLOG(IPAR(-1)) & -1.67545 & -0.032265 & 0.007235 & 0.038362 \\
& {$[-0.93849]$} & {$[-0.29112]$} & {$[0.04395]$} & {$[0.45892]$} \\
DLOG(YSAR(-1)) & -6.256137 & 0.094540 & -0.980425 & -0.249769 \\
& {$[-1.36467]$} & {$[0.33219]$} & {$[-2.31947]$} & {$[-1.16356]$} \\
C & 0.045748 & 0.015160 & 0.028380 & 0.049133 \\
$\mathrm{R}^{2}$ & {$[0.18165]$} & {$[0.96961]$} & {$[1.22216]$} & {$[4.16643]$} \\
\hline
\end{tabular}

$t$-stats are reported in parenthesis.

The lag length of the estimated VAR is selected by using AIC criteria. As the regressions of the VAR are in growth rates, so we observed lower $\mathrm{R}^{2}$ except the third regression of private investment. The impact of growth in real public investment upon the real private investment is shown from the respective coefficient in the third regression.

We perform Granger causality (Table 4) for selected variables. It provides insight into the positive impact of public investment on private investment in agriculture sector. The Real public investment along with the labour and value added Granger cause real private investment.

Table 4

VAR Granger Causality/Block Exogeneity Wald Tests

\begin{tabular}{|c|c|c|c|c|c|c|c|}
\hline \multicolumn{8}{|c|}{ Dependent Variable } \\
\hline \multicolumn{2}{|c|}{ DLOG(IGAR) } & \multicolumn{2}{|c|}{ DLOG(LA) } & \multicolumn{2}{|c|}{ DLOG(IPAR) } & \multicolumn{2}{|c|}{$\overline{\text { DLOG(YSAR) }}$} \\
\hline $\begin{array}{c}\text { Explanatory } \\
\text { variables }\end{array}$ & $\overline{\chi^{2}}$ & $\begin{array}{c}\text { Explanatory } \\
\text { variables }\end{array}$ & $\overline{\chi^{2}}$ & $\begin{array}{c}\text { Explanatory } \\
\text { variables }\end{array}$ & $\chi^{2}$ & $\begin{array}{c}\text { Explanatory } \\
\text { variables }\end{array}$ & $\chi^{2}$ \\
\hline DLOG(LA) & $\begin{array}{c}0.635 \\
(0.426)\end{array}$ & DLOG(IGAR) & $\begin{array}{c}0.246 \\
(0.620)\end{array}$ & DLOG(IGAR) & $\begin{array}{l}14.412 \\
(0.000)\end{array}$ & DLOG(IGAR) & $\begin{array}{c}0.118 \\
(0.732)\end{array}$ \\
\hline DLOG(IPAR) & $\begin{array}{c}0.881 \\
(0.348)\end{array}$ & DLOG(IPAR) & $\begin{array}{c}0.085 \\
(0.771)\end{array}$ & DLOG(LA) & $\begin{array}{l}14.657 \\
(0.000)\end{array}$ & DLOG(LA) & $\begin{array}{c}2.116 \\
(0.146)\end{array}$ \\
\hline DLOG(YSAR) & $\begin{array}{c}1.862 \\
(0.172)\end{array}$ & DLOG(YSAR) & $\begin{array}{c}0.110 \\
(0.740)\end{array}$ & DLOG(YSAR) & $\begin{array}{c}5.380 \\
(0.020)\end{array}$ & DLOG(IPAR) & $\begin{array}{c}0.211 \\
(0.646)\end{array}$ \\
\hline ALL & $\begin{array}{c}2.615 \\
(0.455)\end{array}$ & All & $\begin{array}{c}0.574 \\
(0.902)\end{array}$ & All & $\begin{array}{l}22.488 \\
(0.000)\end{array}$ & All & $\begin{array}{c}2.390 \\
(0.495)\end{array}$ \\
\hline
\end{tabular}

Level of Significance is presented in parenthesis.

The Chart 1 confirms the stability condition of the VAR model, and allows us to perform the impulse response analysis. 
Chart 1

Inverse Roots of AR Characteristic Polynomial

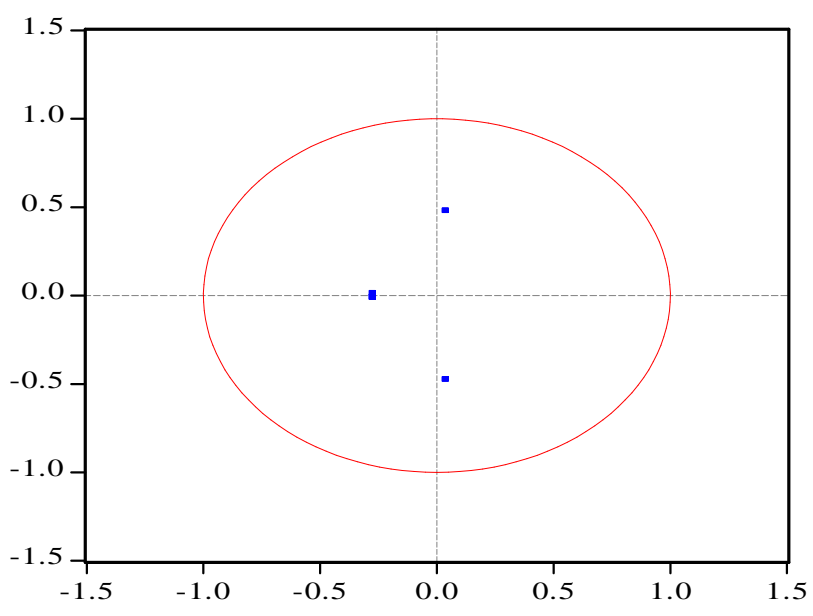

We now focus on the impulse responses analysis. The impulse responses present the dynamic responses of the variables to the fundamental economic disturbances plotted against the number of years that have elapsed since the shock occurred. These are obtained by inverting the structural VAR to obtain its moving average representation using Eviews 5. Impulse responses of one standard deviation public investment shock are shown in Chart A-1. The accumulated responses are obtained by cumulating the impulse responses of growth rates that can be interpreted as the percent deviation of the levels of the variables from baseline, plotted over the number of years that have elapsed since the shock. The response of one standard deviation shock in public investment increases the private investment in level. Therefore, it can be concluded that changes in real public investment crowds in real private investment in agriculture sector.

Variance decomposition measures the percentage of the forecast error variances at various forecast horizons that are attributable to each of individual shocks or group of shocks. These are presented in Table 5.

Table 5

Variance Decomposition of DLOG(IPAR)

\begin{tabular}{cccccc}
\hline Period & S.E. & DLOG(IGAR) & DLOG(LA) & DLOG(IPAR) & DLOG(YSAR) \\
\hline 1 & 0.080058 & 10.27788 & 8.993901 & 80.72822 & 0.000000 \\
& & $(11.8407)$ & $(10.2181)$ & $(14.4649)$ & $(0.00000)$ \\
2 & 0.117830 & 18.58982 & 32.98829 & 37.66063 & 10.76125 \\
& & $(13.9844)$ & $(14.9389)$ & $(11.7880)$ & $(8.24889)$ \\
3 & 0.119085 & 18.30751 & 32.35170 & 38.46226 & 10.87853 \\
& & $(13.2404)$ & $(14.2953)$ & $(11.3838)$ & $(8.15645)$ \\
4 & 0.120626 & 18.57242 & 32.64853 & 37.54992 & 11.22913 \\
& & $(13.2811)$ & $(14.3008)$ & $(11.3017)$ & $(8.36667)$ \\
5 & \multirow{2}{*}{0.120691} & 18.55232 & 32.62470 & 37.57906 & 11.24392 \\
& & $(13.2531)$ & $(14.3143)$ & $(11.2986)$ & $(8.43118)$ \\
\hline
\end{tabular}


As shown in table, at a one year forecast horizon, only about 10.3 percent of the forecast error variance of the changes in the real private investment can be accounted for by real public investment shock. But this rises to 18.6 percent for a 5 -year horizon. Thus, real public investment appears to be important for real private investment fluctuations, which is plausible.

Government's spending in agricultural infrastructure will increase the rate of return on investment in agriculture and hence private investment increases in agriculture when public investment increases.

\section{Manufacturing Sector}

Table 6 of correlation matrix provides some insights about the direction of relationship between the variables under discussion for this sector. Growth in public investment is negatively correlated with private investment growth. It shows that increase in public investments may crowd out private investment. In order to search some further evidences in this regard, we estimated a structural VAR model in which four endogenous variables are included.

Table 6

Correlation Matrix

\begin{tabular}{lcccc}
\hline & DLOG(IGMR) & DLOG(LM) & DLOG(IPMR) & DLOG(YSMR) \\
\hline DLOG(IGMR) & 1.00 & & & \\
DLOG(LM) & -0.29 & 1.00 & & \\
DLOG(IPMR) & -0.31 & -0.01 & 1.00 & 1.00 \\
DLOG(YSMR) & -0.05 & -0.28 & 0.11 & 1.00 \\
\hline
\end{tabular}

The lag order of 2 is selected by minimised AIC statistics for our dynamic VAR specification. The estimated VAR is reported below. The impact of growth in real public investment upon the real private investment is shown from the respective coefficient in the third regression.

Table 7

VAR Estimates of Manufacturing Sector

\begin{tabular}{|c|c|c|c|c|}
\hline \multirow[b]{2}{*}{ Explanatory Variables } & \multicolumn{4}{|c|}{ Dependent Variables } \\
\hline & DLOG(IGMR) & DLOG(LM) & DLOG(IPMR) & DLOG(YSMR) \\
\hline \multirow[t]{2}{*}{ DLOG(IGMR(-1)) } & -0.244 & 0.014 & 0.034 & 0.012 \\
\hline & {$[-1.05]$} & {$[0.60]$} & {$[0.65]$} & [ 1.36$]$ \\
\hline \multirow[t]{2}{*}{ DLOG(IGMR(-2)) } & 0.049 & -0.020 & -0.011 & 0.010 \\
\hline & {$[0.22]$} & {$[-0.91]$} & {$[-0.23]$} & {$[1.15]$} \\
\hline \multirow[t]{2}{*}{ DLOG(LM(-1)) } & -2.037 & 0.015 & -0.161 & 0.261 \\
\hline & {$[-0.967]$} & [ 0.07] & {$[-0.34]$} & [ 3.29] \\
\hline \multirow[t]{2}{*}{ DLOG(LM(-2)) } & 1.581 & 0.201 & 0.263 & 0.222 \\
\hline & {$[0.71]$} & [ 0.93] & {$[0.53]$} & [ 2.64] \\
\hline \multirow[t]{2}{*}{ DLOG(IPMR(-1)) } & -0.486 & -0.001 & 0.014 & 0.001 \\
\hline & {$[-0.58]$} & {$[-0.017]$} & {$[0.07]$} & {$[0.03]$} \\
\hline \multirow[t]{2}{*}{ DLOG(IPMR(-2)) } & -0.828 & -0.119 & -0.036 & 0.080 \\
\hline & {$[-1.02]$} & {$[-1.51]$} & {$[-0.20]$} & [ 2.63] \\
\hline \multirow[t]{2}{*}{ DLOG(YSMR(-1)) } & -2.841 & 0.333 & -0.612 & 0.461 \\
\hline & {$[-0.68]$} & [ 0.82] & {$[-0.66]$} & [ 2.91] \\
\hline \multirow[t]{2}{*}{ DLOG(YSMR(-2)) } & 2.389 & -0.083 & 1.360 & 0.350 \\
\hline & [ 0.58$]$ & {$[-0.21]$} & [ 1.48] & [ 2.24] \\
\hline $\mathrm{R}^{2}$ & 0.134 & 0.166 & 0.112 & 0.533 \\
\hline
\end{tabular}


Granger causality (Table 8) for selected variables is performed. It is unable to provide any valuable information regarding our institution. But it confirms that growth in employed labour and growth in private investment has significant positive impact on the value added of this sector.

Table 8

VAR Granger Causality/Block Exogeneity Wald Tests

\begin{tabular}{lcccccccc}
\hline \multicolumn{1}{c}{} & \multicolumn{9}{c}{ Dependent Variable } \\
\cline { 2 - 5 } DLOG(IGMR) & \multicolumn{2}{c}{ DLOG(LM) } & \multicolumn{2}{c}{ DLOG(IPMR) } & \multicolumn{2}{c}{ DLOG(YSMR) } \\
& $\chi^{2}$ & & $\chi^{2}$ & & $\chi^{2}$ & $\chi^{2}$ \\
\hline DLOG(LM) & 1.383 & DLOG(IGMR) & 1.273 & DLOG(IGMR) & 0.504 & DLOG(IGMR) & 2.951 \\
& $(0.501)$ & & $(0.529)$ & & $(0.777)$ & & $(0.229)$ \\
DLOG(IPMR) & 1.485 & DLOG(IPMR) & 2.306 & DLOG(LM) & 0.385 & DLOG(LM) & 18.451 \\
& $(0.476)$ & & $(0.316)$ & & $(0.825)$ & & $(0.000)$ \\
DLOG(YSMR) & 0.458 & DLOG(YSMR) & 1.705 & DLOG(YSMR) & 3.802 & DLOG(IPMR) & 6.974 \\
& $(0.796)$ & & $(0.426)$ & & $(0.149)$ & & $(0.031)$ \\
ALL & 3.310 & ALL & 4.615 & ALL & 4.779 & ALL & 22.177 \\
& $(0.769)$ & & $(0.594)$ & & $(0.573)$ & & $(0.001)$ \\
\hline
\end{tabular}

Inverse roots of AR characteristic polynomial graphed in Chart 2 confirm the stability condition of the VAR model and enable us to perform the impulse response analysis.

Chart 2

Inverse Roots of AR Characteristic Polynomial

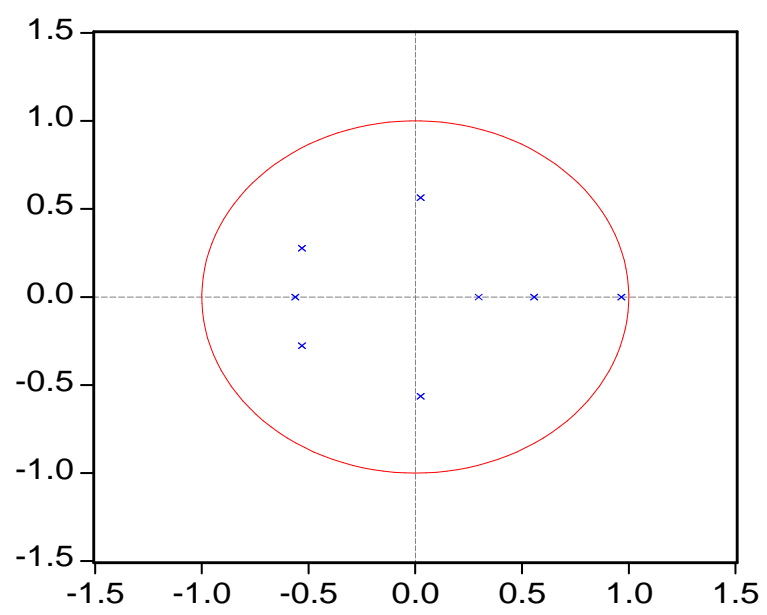

We now focus on the impulse responses analysis in the manufacturing sector. Impulse responses of one standard deviation public investment shock are shown in Chart A-2. The accumulated responses are obtained by cumulating the impulse responses of growth rates that can be interpreted as the percent deviation of the levels of the variables from baseline, plotted over the number of years that have elapsed since the shock. The response of one standard deviation shock in public investment decelerates the private investment in level. Therefore, it can be concluded that changes in real public investment crowds out real private investment in manufacturing sector. 
As shown in Table 9, at a one year forecast horizon, only about 7.6 percent of the forecast error variance of the changes in the real private investment can be accounted for by real public investment shock. But this rises to only 10.6 percent for a 5-year horizon. Thus, real public investment appears to be less important for real private investment fluctuations.

Table 9

Variance Decomposition of DLOG(IPMR)

\begin{tabular}{cccccc}
\hline Period & S.E. & DLOG(IGMR) & DLOG(LM) & DLOG(IPMR) & DLOG(YSMR) \\
\hline 1 & 0.700608 & 7.610069 & 1.031351 & 91.35858 & 0.000000 \\
& & $(9.40478)$ & $(5.07282)$ & $(10.1417)$ & $(0.00000)$ \\
2 & 0.721268 & 10.04256 & 1.249820 & 87.72820 & 0.979424 \\
& & $(10.8643)$ & $(6.24241)$ & $(11.8027)$ & $(3.64004)$ \\
3 & \multirow{2}{*}{0.736612} & 10.66972 & 1.204129 & 85.04530 & 3.080858 \\
& & $(11.7106)$ & $(6.91527)$ & $(12.5809)$ & $(4.82825)$ \\
4 & \multirow{2}{*}{0.741401} & 10.73996 & 1.655686 & 84.07548 & 3.528880 \\
& & $(11.8364)$ & $(7.36374)$ & $(13.1472)$ & $(4.74764)$ \\
5 & \multirow{2}{*}{0.742790} & 10.61038 & 2.186230 & 83.26654 & 3.936845 \\
& & $(12.0083)$ & $(7.56322)$ & $(13.4729)$ & $(5.10025)$ \\
\hline
\end{tabular}

Public investment in heavily subsidised and inefficient state owned enterprises along with higher budget deficit, because higher budget deficit will leads to higher tax rates or decrease in government expenditures (like development expenditures in LDCs) more often reduces the possibilities for private investment and hence public investment in manufacturing crowds out private investment.

\section{Overall}

During the analysis of two main commodity producing sectors, the results are quite reverse. As agriculture sector is characterised with crowding in whereas in manufacturing sector crowding out exists. It would be nicer if we could manage to find out the relationship in overall economy. Template of the results is quite in order of above sectors. Starting with correlation matrix, that provides a negative correlation between private and public investments.

Table 10

Correlation Matrix

\begin{tabular}{lcccc}
\hline & DLOG(IPUBR) & DLOG(LABIND) & DLOG(IPR) & DLOG(YSFCR) \\
\hline DLOG(IPUBR) & 1.00 & & & \\
DLOG(LABIND) & -0.16 & 1.00 & & \\
DLOG(IPR) & -0.25 & 0.06 & 1.00 & \\
DLOG(YSFCR) & 0.21 & -0.18 & -0.08 & 1.00 \\
\hline
\end{tabular}

The results of estimated VAR are reported in Table 11. AIC criteria suggested a lag length of 3. Contrary to correlation matrix, coefficients of public investment in the equation of private investment are suggesting a positive impact that crowding in exists. 
Table 11

VAR Estimates of Overall

\begin{tabular}{|c|c|c|c|c|}
\hline \multirow[b]{2}{*}{ Explanatory Variables } & \multicolumn{4}{|c|}{ Dependent Variables } \\
\hline & DLOG(IPUBR) & DLOG(LABIND) & DLOG(IPR) & DLOG(YSFCR) \\
\hline \multirow{2}{*}{ DLOG(IPUBR(-1)) } & 0.003 & -0.073 & 0.029 & -0.042 \\
\hline & {$[0.01]$} & {$[-2.32]$} & {$[0.27]$} & {$[-1.48]$} \\
\hline \multirow{2}{*}{ DLOG(IPUBR(-2)) } & 0.271 & 0.006 & 0.062 & -0.002 \\
\hline & {$[1.43]$} & {$[0.24]$} & {$[0.72]$} & {$[-0.10]$} \\
\hline \multirow{2}{*}{ DLOG(IPUBR(-3)) } & -0.293 & 0.094 & 0.052 & 0.020 \\
\hline & {$[-1.24]$} & {$[2.86]$} & {$[0.48]$} & {$[0.66]$} \\
\hline \multirow{2}{*}{ DLOG(LABIND(-1)) } & -1.724 & -0.101 & -0.408 & -0.106 \\
\hline & {$[-1.30]$} & {$[-0.55]$} & {$[-0.67]$} & {$[-0.64]$} \\
\hline \multirow{2}{*}{ DLOG(LABIND(-2)) } & 3.467 & -0.263 & -0.656 & 0.262 \\
\hline & {$[2.58]$} & {$[-1.41]$} & {$[-1.07]$} & [ 1.56$]$ \\
\hline \multirow{2}{*}{ DLOG(LABIND(-3)) } & 2.031 & 0.077 & -0.118 & 0.202 \\
\hline & [ 1.24$]$ & {$[0.34]$} & {$[-0.16]$} & [ 0.99$]$ \\
\hline \multirow{2}{*}{ DLOG(IPR(-1)) } & 0.181 & 0.033 & -0.273 & -0.040 \\
\hline & {$[0.36]$} & {$[0.48]$} & {$[-1.20]$} & {$[-0.64]$} \\
\hline \multirow{2}{*}{ DLOG(IPR(-2)) } & 0.720 & -0.096 & -0.219 & 0.086 \\
\hline & [ 1.66$]$ & {$[-1.61]$} & {$[-1.11]$} & {$[1.58]$} \\
\hline \multirow{2}{*}{ DLOG(IPR(-3)) } & 0.262 & 0.059 & -0.264 & -0.014 \\
\hline & {$[0.63]$} & {$[1.02]$} & {$[-1.39]$} & {$[-0.28]$} \\
\hline \multirow{2}{*}{ DLOG(YSFCR(-1)) } & 3.387 & -0.005 & 0.647 & 0.353 \\
\hline & {$[1.68]$} & {$[-0.02]$} & {$[0.70]$} & {$[1.40]$} \\
\hline \multirow{2}{*}{ DLOG(YSFCR(-2)) } & -0.819 & 0.678 & 0.837 & 0.306 \\
\hline & {$[-0.43]$} & {$[2.54]$} & {$[0.95]$} & {$[1.28]$} \\
\hline \multirow{2}{*}{ DLOG(YSFCR(-3)) } & 1.127 & -0.707 & 0.033 & 0.075 \\
\hline & {$[0.66]$} & {$[-3.01]$} & {$[0.04]$} & {$[0.35]$} \\
\hline \multirow{2}{*}{$\mathrm{C}$} & -0.330 & 0.030 & 0.039 & 0.005 \\
\hline & {$[-2.32]$} & [ 1.54$]$ & {$[0.60]$} & {$[0.26]$} \\
\hline $\mathrm{R}^{2}$ & 0.600 & 0.511 & 0.462 & 0.564 \\
\hline
\end{tabular}

Granger causality tests also suggest a positive but insignificant impact of public investment growth on private investment.

Table 12

VAR Granger Causality/Block Exogeneity Wald Tests

\begin{tabular}{|c|c|c|c|c|c|c|c|}
\hline \multicolumn{8}{|c|}{ Dependent Variable } \\
\hline \multicolumn{2}{|c|}{ DLOG(IPUBR) } & \multicolumn{2}{|c|}{ DLOG(LABIND) } & \multicolumn{2}{|c|}{ DLOG(IPR) } & \multicolumn{2}{|c|}{ DLOG(YSFCR) } \\
\hline & $\chi^{2}$ & & $\chi^{2}$ & & $\chi^{2}$ & & $\chi^{2}$ \\
\hline DLOG(LABIND) & $\begin{array}{l}11.002 \\
(0.012)\end{array}$ & DLOG(IPUBR) & $\begin{array}{c}9.394 \\
(0.025)\end{array}$ & DLOG(IPUBR) & $\begin{array}{c}1.187 \\
(0.756)\end{array}$ & DLOG(IPUBR) & $\begin{array}{c}2.226 \\
(0.527)\end{array}$ \\
\hline DLOG(IPR) & $\begin{array}{c}3.824 \\
(0.281)\end{array}$ & DLOG(IPR) & $\begin{array}{c}4.033 \\
(0.258)\end{array}$ & DLOG(LABIND) & $\begin{array}{c}1.439 \\
(0.696)\end{array}$ & DLOG(LABIND) & $\begin{array}{c}4.156 \\
(0.245)\end{array}$ \\
\hline DLOG(YSFCR) & $\begin{array}{c}3.873 \\
(0.276)\end{array}$ & DLOG(YSFCR) & $\begin{array}{l}12.769 \\
(0.005)\end{array}$ & DLOG(YSFCR) & $\begin{array}{c}2.384 \\
(0.497)\end{array}$ & DLOG(IPR) & $\begin{array}{c}4.393 \\
(0.222)\end{array}$ \\
\hline ALL & $\begin{array}{l}23.452 \\
(0.005)\end{array}$ & All & $\begin{array}{l}16.042 \\
(0.066)\end{array}$ & All & $\begin{array}{c}8.420 \\
(0.493)\end{array}$ & All & $\begin{array}{l}19.564 \\
(0.021)\end{array}$ \\
\hline
\end{tabular}


Stability conditions are satisfied as are reported in Chart-3.

Chart 3

Inverse Roots of AR Characteristic Polynomial

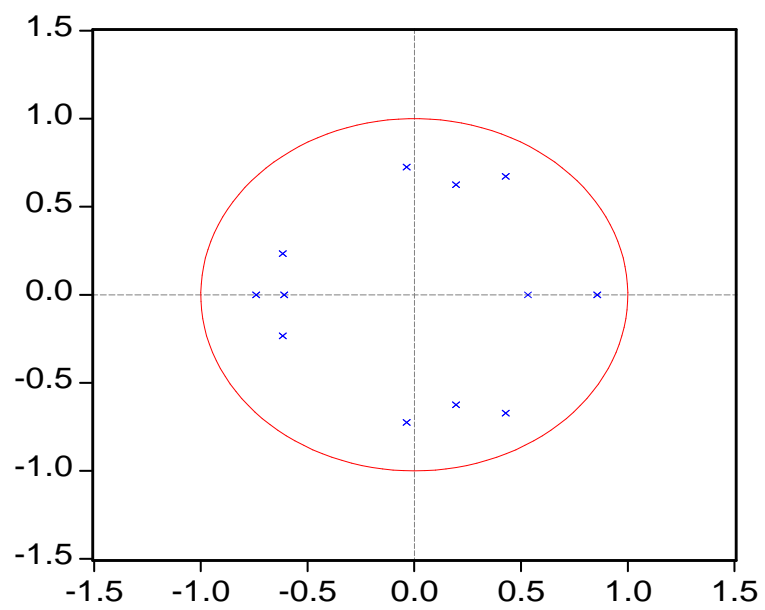

Impulse response analysis is reported in Chart A-3 in the Appendix. Accumulated responses are captured and show that one standard deviation shock in growth of public investment increases in growth of private investment but at a horizon of 5 periods it then reduces growth of private investment.

As shown in Table 13, at a one year forecast horizon, only about 0.29 percent of the forecast error variance of the changes in the real private investment can be accounted for by real public investment shock. That increases just to 7.5 percent for a 5-year horizon. Thus, real public investment appears to be less important for real private investment fluctuations.

Table 13

Variance Decomposition of DLOG(IPR)

\begin{tabular}{cccccc}
\hline Period & S.E. & DLOG(IPUBR) & DLOG(LABIND) & DLOG(IPR) & DLOG(YSFCR) \\
\hline 1 & 0.127078 & 0.292651 & 3.465020 & 96.24233 & 0.000000 \\
& & $(5.20904)$ & $(7.18349)$ & $(8.64168)$ & $(0.00000)$ \\
2 & \multirow{2}{*}{0.147640} & 1.374948 & 4.845635 & 91.57780 & 2.201614 \\
& & $(8.32276)$ & $(7.96746)$ & $(12.0125)$ & $(6.41813)$ \\
\multirow{2}{*}{3} & \multirow{2}{*}{0.159854} & 3.899783 & 9.272312 & 80.45061 & 6.377292 \\
& & $(9.61547)$ & $(9.49178)$ & $(12.8813)$ & $(7.84389)$ \\
\multirow{2}{*}{4} & \multirow{2}{*}{0.186856} & 4.247507 & 10.09182 & 79.33098 & 6.329688 \\
& & $(10.0928)$ & $(9.67517)$ & $(12.9757)$ & $(8.31796)$ \\
& \multirow{2}{*}{5} & 7.478574 & 10.98452 & 75.91496 & 5.621952 \\
& & $(10.9753)$ & $(9.13146)$ & $(13.2076)$ & $(8.19143)$ \\
\hline
\end{tabular}




\section{CONCLUSIONS AND POLICY RECOMMENDATIONS}

This paper investigate the type of relationship that exists between public and private investments. Major commodity-producing sectors, such as agriculture and manufacturing, along with the overall economy are explored for the above inquiry. Sector-wise analysis of the impacts of public investment is mainly explored; this area has not been deeply studied in previous literature. An unrestricted Structural VAR model using the specification of production function is estimated. Increase in public investment encourages private investment in the agriculture sector. Therefore, we can conclude that the crowding-in phenomenon exists in the agriculture sector. However, a negative relationship is found between public investment and private investment in the manufacturing sector and that supports the existence of the crowding-out phenomenon. The estimated regressions of the system for the overall economy, however, reveal no significant impact of public investment upon private investment. These conclusions lead us to simple policy recommendations in which the public sector should concentrate on increase in public investment in the agriculture sector, whereas it should reduce the intervention through public investment in the manufacturing sector.

Table A-1

Appendix

\begin{tabular}{ll}
\hline Variables & \multicolumn{1}{c}{ Description } \\
\hline IPUBR & Real Public Investment (Total) \\
LABIND & Employed Labour Force (Total) \\
YSFCR & Real GDP (FC) \\
IPR & Real Private Investment (Total) \\
LA & Employed Labour Force (Agriculture) \\
YSAR & Real Value added (Agriculture) \\
IPAR & Real Private Investment (Agriculture) \\
IGMR & Real Public Investment (Manufacturing) \\
LM & Employed Labour Force (Manufacturing) \\
YSMR & Real Value Added (Manufacturing) \\
IPMR & Real Private Investment (Manufacturing) \\
IGAR & Real Public Investment (Agriculture) \\
\hline
\end{tabular}

All the variables are collected from various issues of the Pakistan Economic Survey. The data are collected from 1973-2006, with annual frequencies. 
Chart A-1. Accumulated Response to Cholesky One S.D. Innovations in DLOG(IGAR)
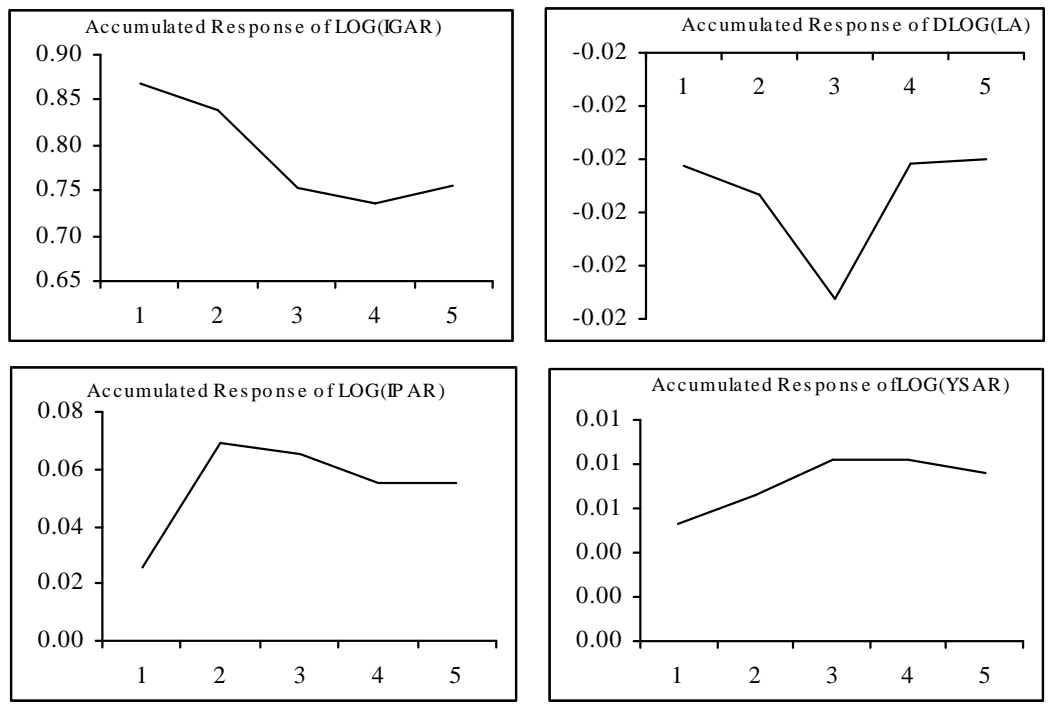

\section{Accumulated Response to Cholesky One S.D. Innovations in DLOG(LA)}
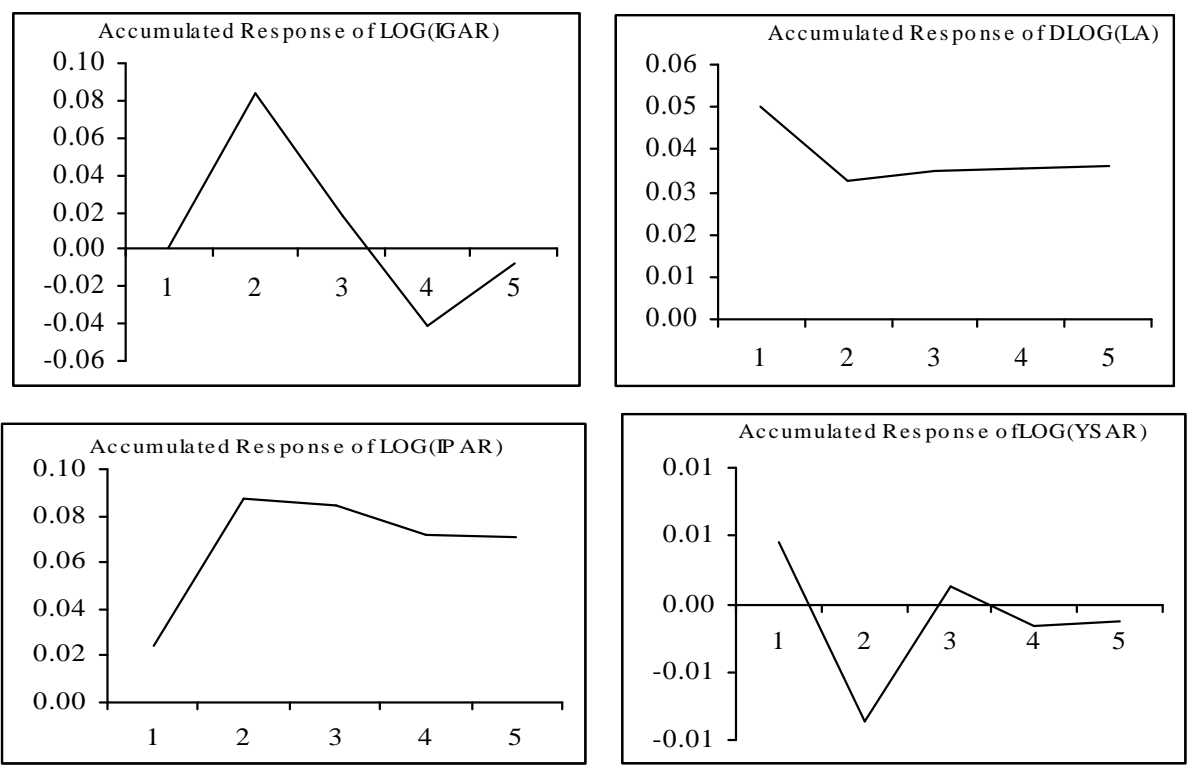
Accumulated Response to Cholesky One S.D. Innovations in DLOG(IPAR)
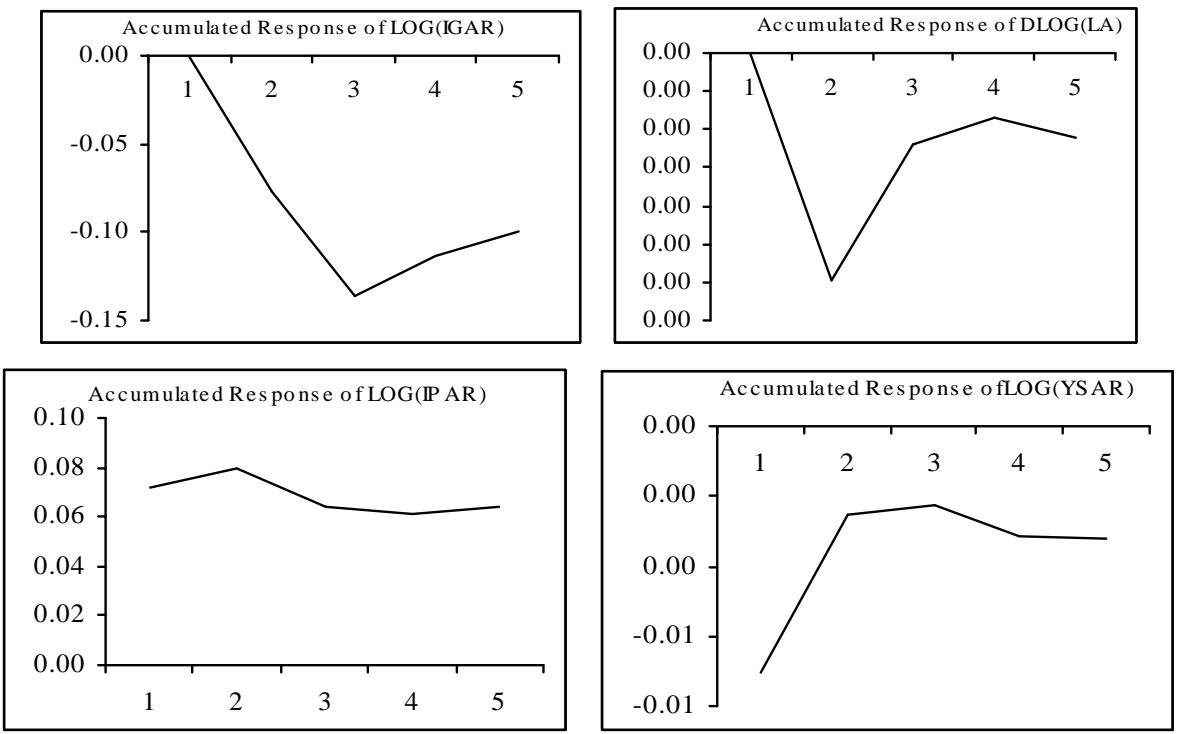

\section{Accumulated Response to Cholesky One S.D. Innovations in DLOG(YSAR)}
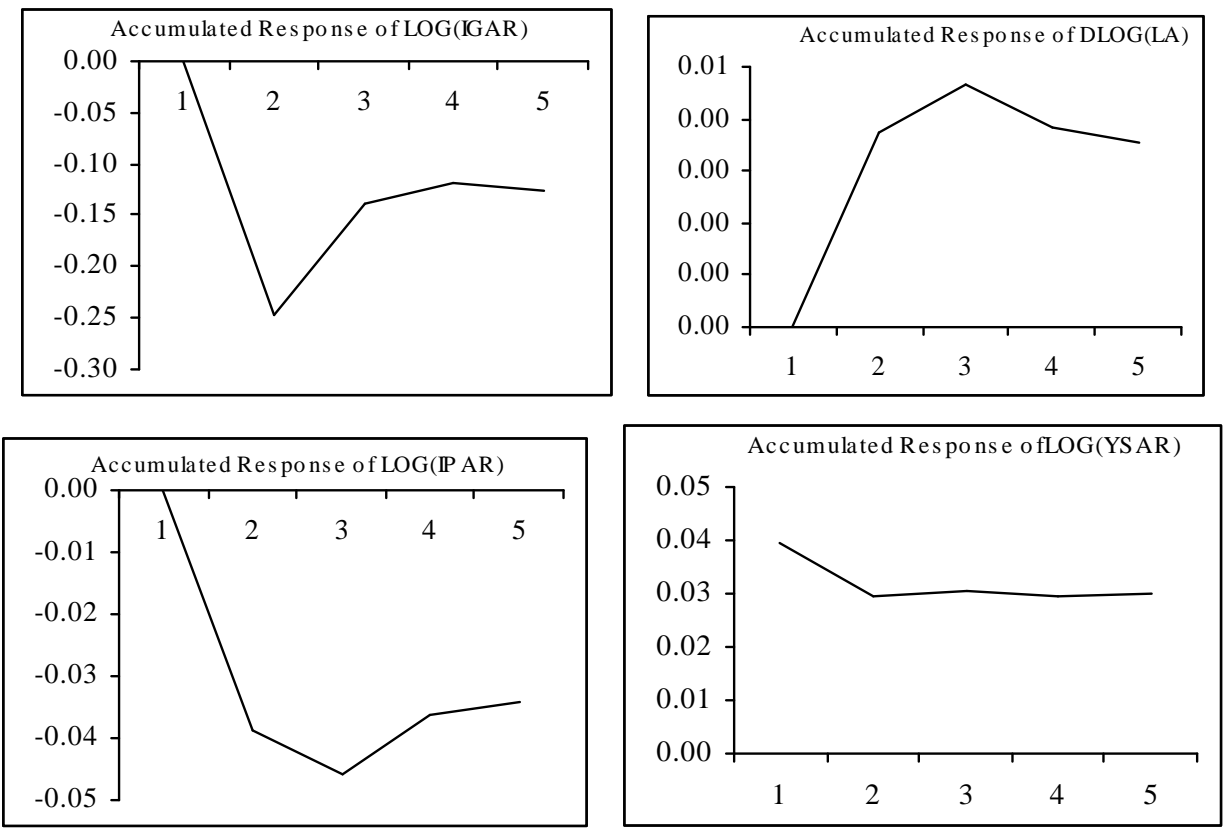
Chart A-2. Accumulated Response to Cholesky One S.D. Innovations in DLOG(IGMR)
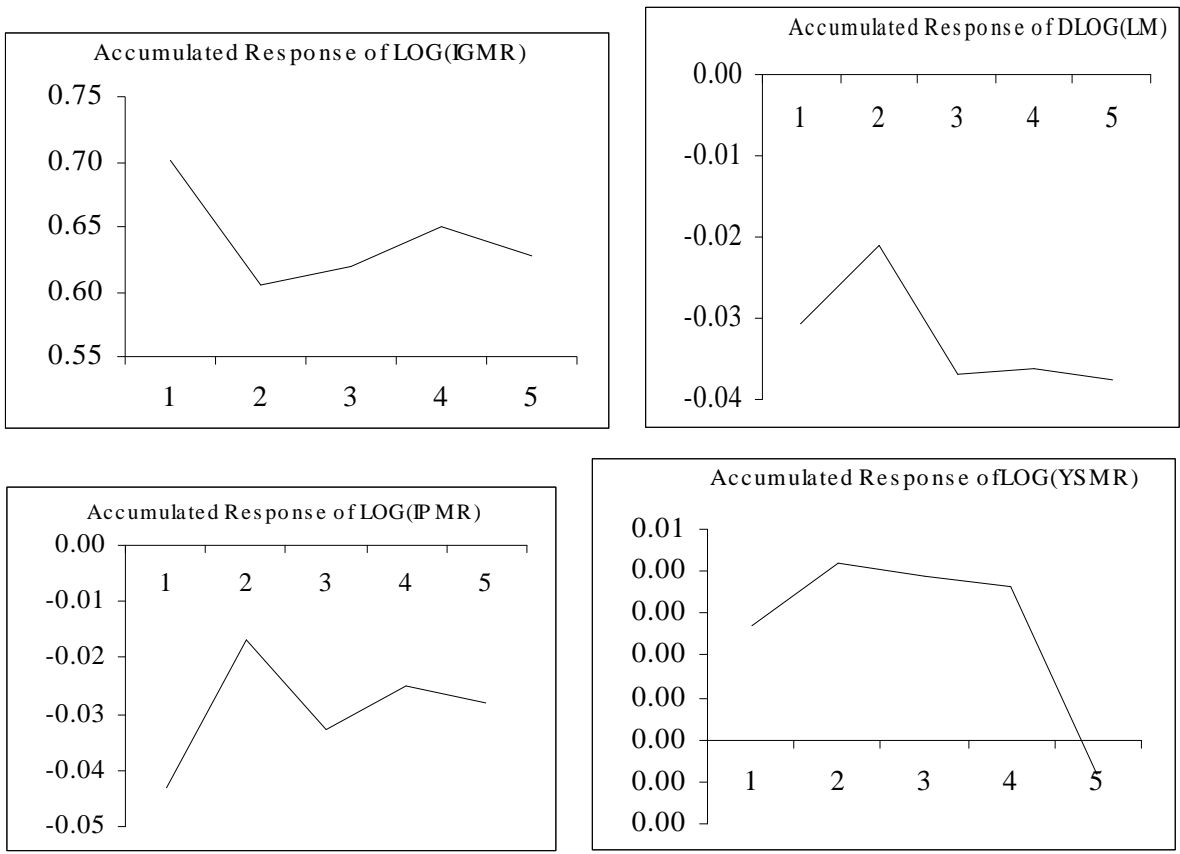

Accumulated Response to Cholesky One S.D. Innovations in DLOG(LM)
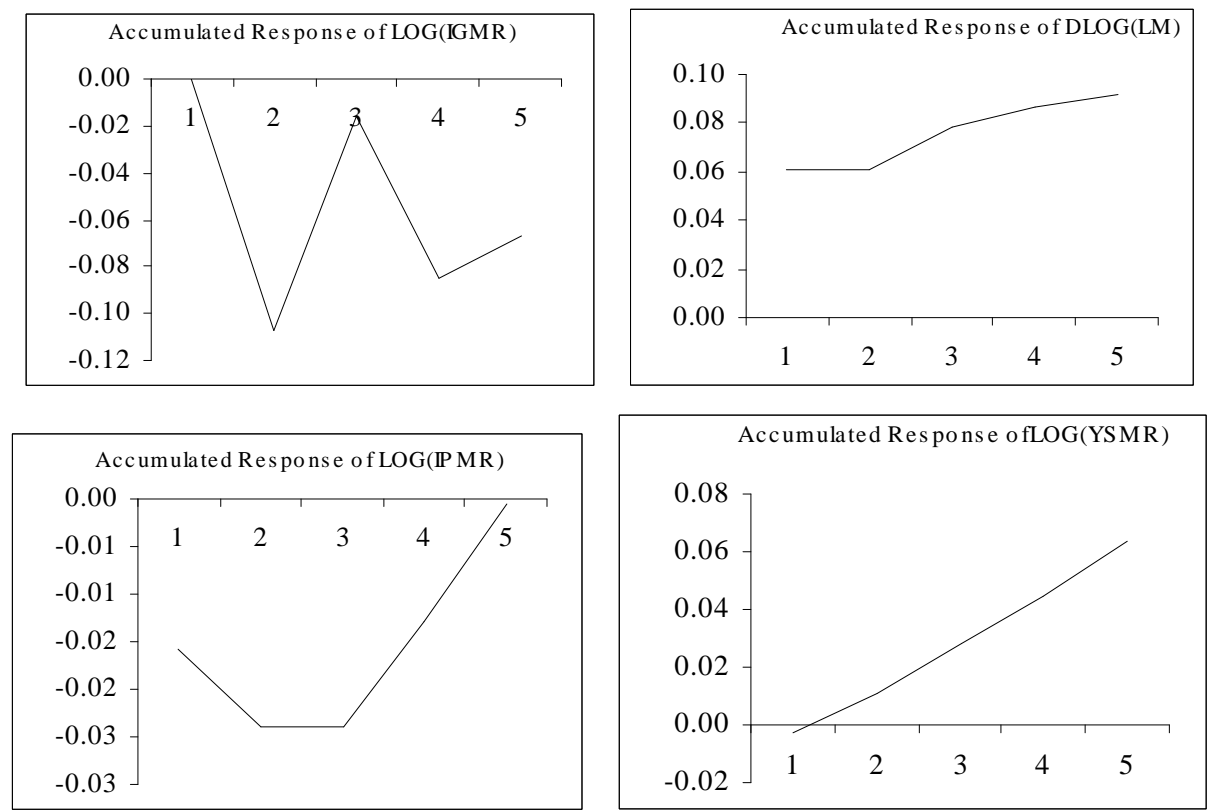
Accumulated Response to Cholesky One S.D. Innovations in DLOG(IPMR)
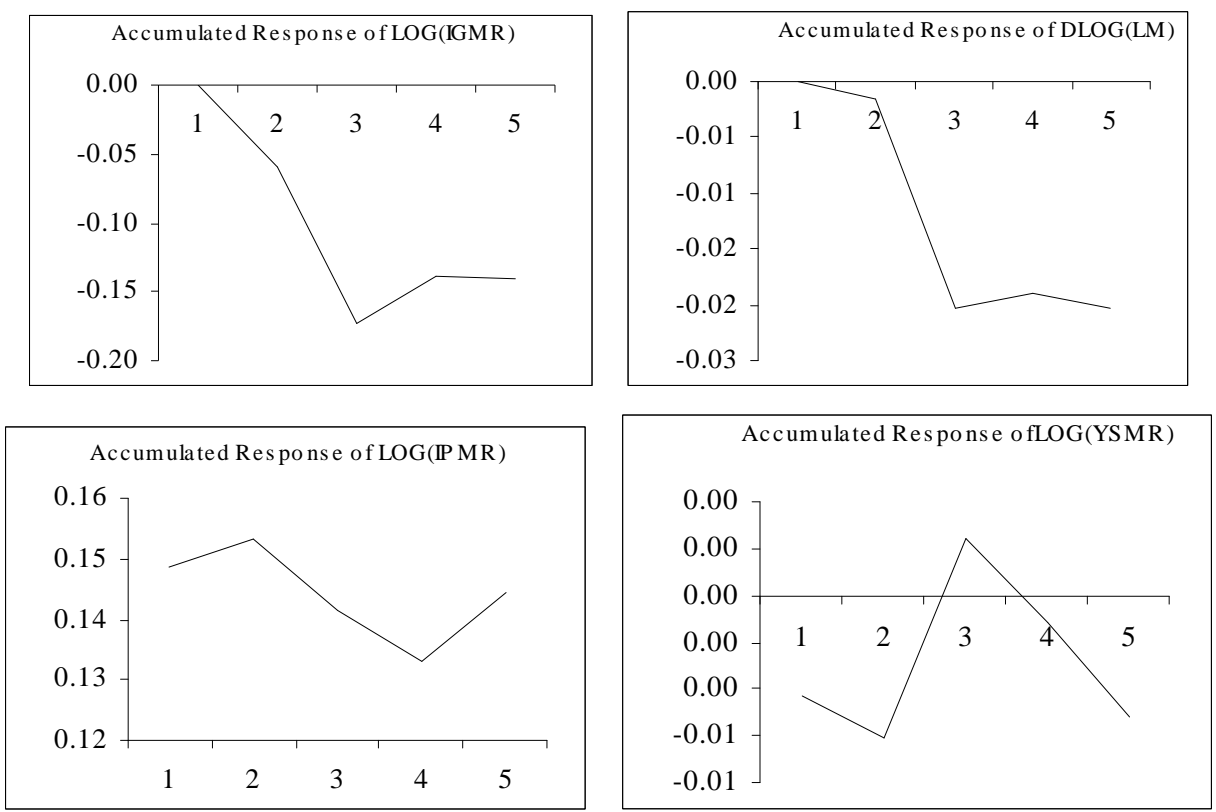

\section{Accumulated Response to Cholesky One S.D. Innovations in DLOG(YSMR)}
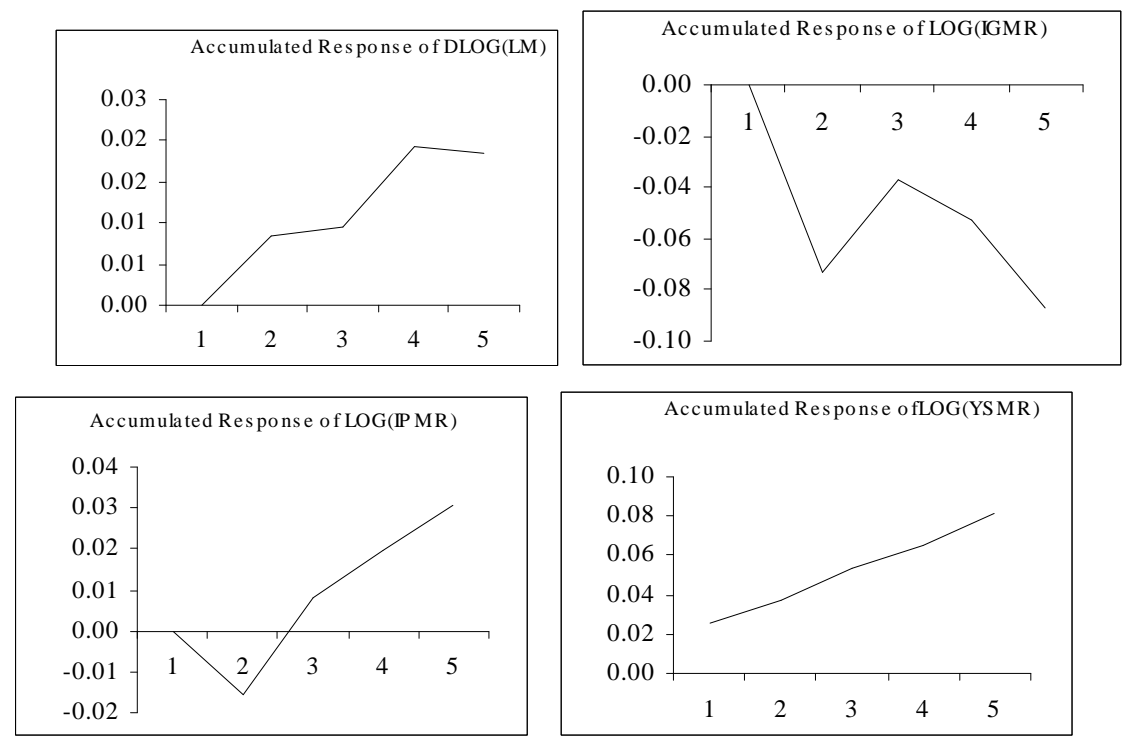
Chart A-3. Accumulated Response to Cholesky One S.D. Innovations in DLOG(IPUBR)
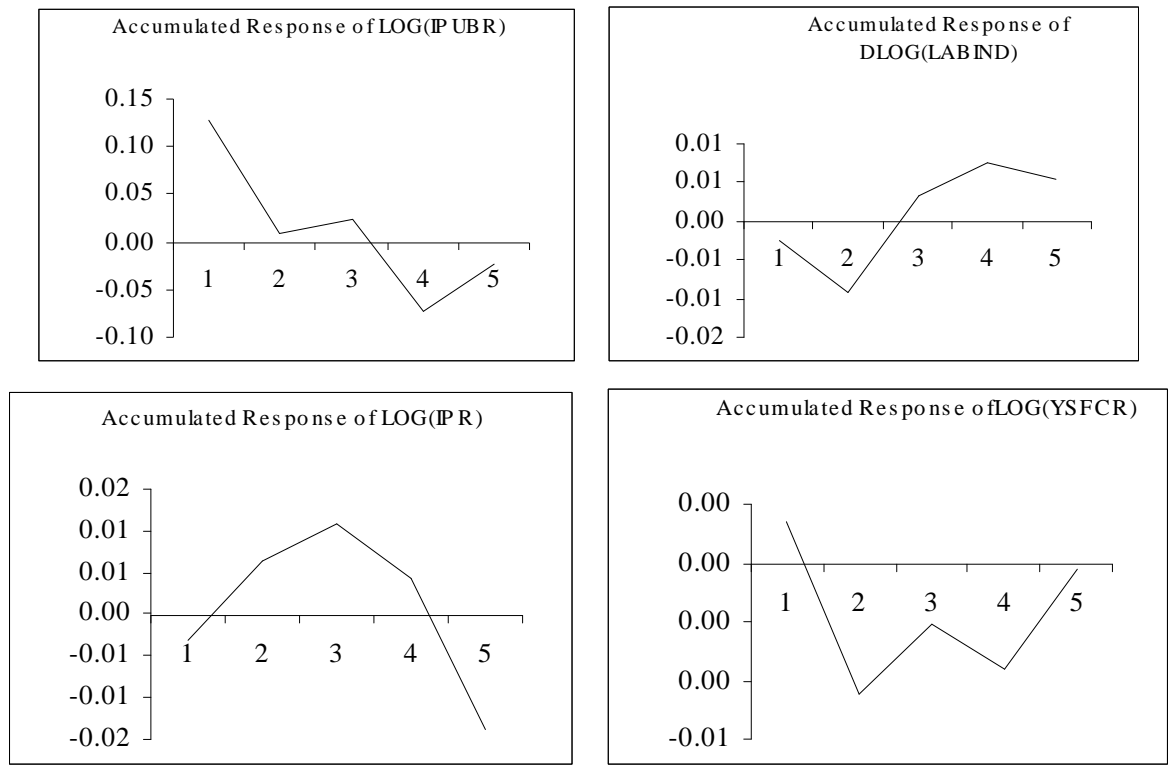

\section{Accumulated Response to Cholesky One S.D. Innovations in DLOG(LABIND)}
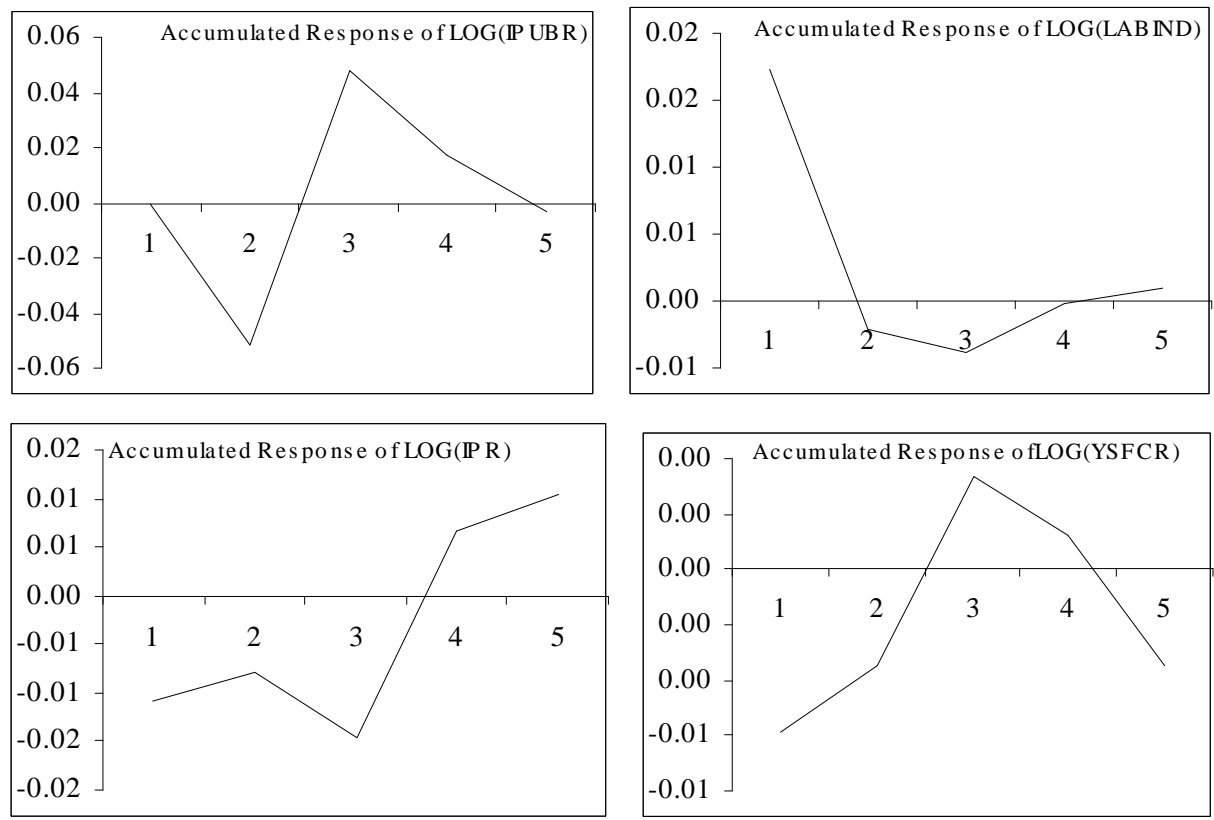
Accumulated Response to Cholesky One S.D. Innovations in DLOG(IPR)
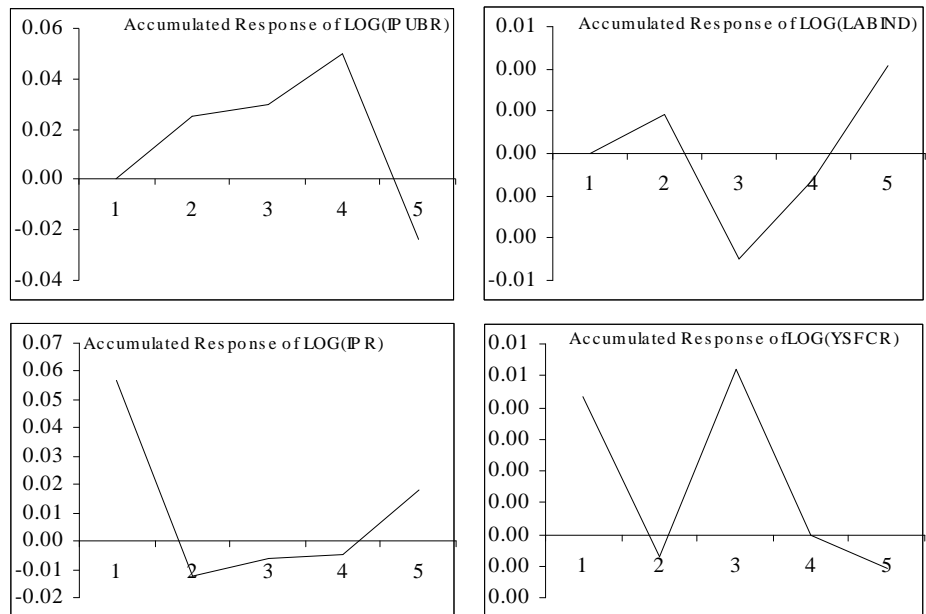

\section{Accumulated Response to Cholesky One S.D. Innovations in DLOG(YSFCR)}
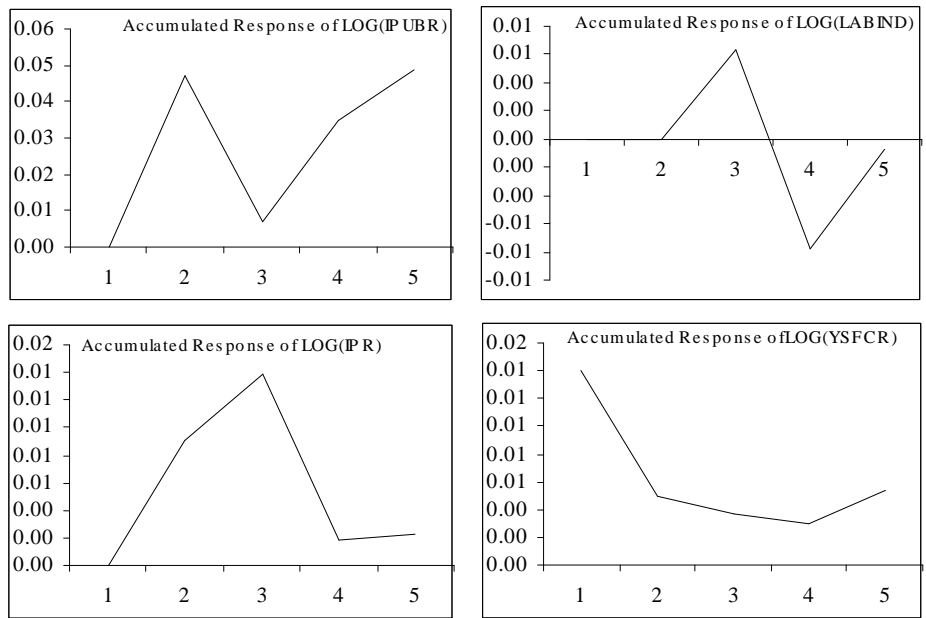

\section{REFERENCES}

Ahmed, M. (1994) The Effects of Government Budget Deficits on the Interest Rates: A Case Study of a Small Open Economy. Economia Internazionale 1, 1-6.

Aisha, A. F. and H. A. Pasha (2000) Macroeconomic Framework for Debt Management. Social Policy and Development Centre. (Policy Paper No. 19.)

Aschauer, D. A. (1988) Government Spending and the Falling Rate of Profit. Economic Perspectives 6, 11-17.

Barth, J. R. and J. J. Cordes (1980) Substitutability, Complementarity, and the Impact of Government Spending on Economic Activity. Journal of Economic and Business 2, 235-42. 
Burney, N. A. and A. Yasmeen (1989) Government Budget Deficit and Interest Rates: An Empirical Analysis of Pakistan. The Pakistan Development Review 28:4, 971-80.

Dickey, D. A. and W. A. Fuller (1979) Distribution of the Estimators for Autoregressive Time Series with a Unit Root. Journal of American Statistical Association 75, 427831.

Engle, R. E. and C. W. J. Granger (1987) Cointegration and Error Correction: Representation, Estimation and Testing. Econometrica 55, 251-76.

Erenburg, S. J. and Mark E. Wohar (1995) Public and Private Investment: Are there Causal Linkages. Journal of Macroeconomics 17:1, 1-30.

Ghali, K. H. (1998) Public Investment and Private Capital Formation in a Vector Errorcorrection Model of Growth. Applied Economics 6, 837-44.

Haque, N. U. and P. J. Montial (1993) Fiscal Adjustment in Pakistan: Some Simulation Results. International Monetary Fund Staff Papers 40:2, 471-80.

Hyder, Kalim (2001) Crowding-out Hypothesis in a Vector Error Correction Frame Work: A Case Study of Pakistan. The Pakistan Development Review 40:4, 633-49.

Khan, A. H. and Z. Iqbal (991) Fiscal Deficit and Private Sector Activities in Pakistan. Economia Internazionale 2-3, 182-90.

Khan, A. H., H. Lubna, and A. Malik (1992) Dependency Ratio, Foreign Capital Inflows and the Rte of Sving in Pakistan. The Pakistan Development Review 31:4, 843-56.

Looney, R. E. (1995) Public Sector Deficits and Private Investment: A Test of the Crowding-Out Hypothesis in Pakistan's Manufacturing Industry. The Pakistan Development Review 34:3, 277-97.

Looney, Robert E. (1994) The Impact of Infrastructure on Pakistan's Agriculture Sector. Journal of Developing Areas 28:4, 469-86.

Looney, Robert E. (1999) Government Investment in Manufacturing: Stimulus or Hindrance to Pakistan's Private Sector? International Journal of Social Economics 26:4, 521-36.

Monadjemi, M. S. (1996) Public Expenditure and Private Investment: A Study of Three OECD Countries. University of Kent Working Paper Series.

Naqvi, Naveed H. (2002) Crowding-in or Crowding Out? Modeling the Relationship between Public and Private Fixed Capital Formation. The Pakistan Development Review 41:3 255-76.

Narayan, Paresh Kumar (2004) Do Public Investment Crowds Out Private Investment? Fresh evidence from Fiji. Journal of Policy Modeling 26:6, 747-753.

Pereira, Alfred M. and Oriol Roca-Sagales (2001) Infrastructure and Private Sector Performance in Spain. Journal of Policy Modeling 23: 4, 371-84.

Pereira, Alfredo M. (2001) On the effects of Public Investment on Private Investment: What Crowds in What? Public Finance Review 29:1.

Pereira, Alfredo M. and Jorge M. Andraz (2003) The Effects of Public Investment on Private Investment: On Different US Industries. Public Finance Review. January.

Philips, P. C. B. and P. Perron (1988) Testing for a Unit Root in Time Series Regression. Biometrica 75, 335-46.

Pradhan, B. K., D. K. Ratha, and Atul Sarma (1990) Complementarity between Public and Private Investment in India. Journal of Development Economics 33:1, 101-16. 
Ramirez, M. D. (1994) Public and Private Investment in Mexico 1950-90: An empirical Analysis. Southern Economic Journal 61, 1-17.

Social Policy and Development Centre (1995) Integrated Social Policy and Macro Economic Planning Model for Pakistan. (Research Report No. 7.)

Social Policy and Development Centre (2001) Stabilisation versus Growth. (Research Report No. 40.)

Voss, Graham M. (2002) Public and Private Investment in United States and Canada. Economic Modeling 29:4, 641-64. 